\title{
Distribution and ecology of the caddisflies (Trichoptera) of Flanders (Belgium)
}

\author{
Koen Lock* and Peter L.M. Goethals \\ Laboratory of Environmental Toxicology and Aquatic Ecology, Ghent University, J. Plateaustraat 22, 9000 Gent, Belgium
}

Received 26 March 2011; Accepted 7 September 2011

\begin{abstract}
Based on a literature survey and the identification of all available collection material, a checklist and distribution maps for the caddisflies occurring in Flanders were prepared. Of the 126 species that have been recorded, 16 are now extinct in Flanders, while the majority of the remaining species is rare and their populations are often vulnerable due to isolation. Caddisflies only occurred at high oxygen levels and relatively low conductivities and three species assemblages could be recognized. A first group of species lived in stagnant waters and those species tolerated slightly lower oxygen concentrations than species characteristic for running waters. In streams of the Campine region, which are characterized by a low $\mathrm{pH}$ and a low conductivity, a second group of species was found. The last group of species mainly occurred in the loamy region, where $\mathrm{pH}$ and conductivity are higher. Running waters in other ecoregions mainly contained ubiquist species and did not possess a characteristic species assemblage. Despite the fact that the ecological water quality in Flanders slightly increased during the last few decades, the ecological water quality of most waters is still too low for caddisflies. According to the European Union water framework directive, a good ecological water quality should be obtained in all surface waters. Additional measures to improve the water quality are necessary in order to obtain sustainable populations of the caddisfly species occurring in Flanders.
\end{abstract}

Key words: Checklist / distribution maps / habitat suitability

\section{Introduction}

Due to habitat destruction and degradation, pollution, flow modification and invasion by exotic species, fresh waters are experiencing declines in biodiversity far greater than those in the most affected terrestrial ecosystems (Sala et al., 2000). Although some industrialized countries have made considerable progress in reducing water pollution from domestic and industrial point sources, threats from excessive nutrient enrichment are still growing (Smith, 2003) and the number of alien species keeps increasing (Messiaen et al., 2010). Also in Flanders, river management has until the present mainly been conducted at the river basin level by installing wastewater treatment plants and imposing standards for effluent concentrations. Although these measures have already resulted in a significant improvement of the chemical and ecological water quality since the 1980s (VMM, 2010), most Flemish water bodies still lack the good ecological status which the European Union Water Framework Directive (WFD) requires by 2015 (European Council, 2000).

\footnotetext{
*Corresponding author: Koen_Lock@hotmail.com
}

In order to assess the ecological water quality, the use of biotic indicators (macrobenthic fauna, fish fauna, phytoplankton, phytobenthos and macrophytes) is required by the WFD. Until recently, the Flemish Environment Agency used the Belgian Biotic Index (BBI) to evaluate the ecological water quality based on the occurring macro-invertebrates (De Pauw and Vanhooren, 1983). In order to meet the requirements of the WFD, the Multimetric Macroinvertebrate Index Flanders (MMIF; Gabriels et al., 2010) was developed, which is a type-specific multi-metric index consisting of five equally weighted metrics: taxa richness, the number of EPT taxa (Ephemeroptera, Plecoptera and Trichoptera), the number of other sensitive taxa, the Shannon-Wiener diversity index and the mean tolerance score. In both the BBI and the MMIF, caddisflies are indicated as one of the most sensitive groups of macroinvertebrates, which are characteristics of waters with a high ecological quality.

Nature conservation policy in Belgium is the responsibility of the regional governments (Flanders, Brussels and Wallonia) and a regional scale is thus appropriate to perform faunistic studies or to develop red lists. Flanders, which is the Dutch-speaking part of Belgium, 

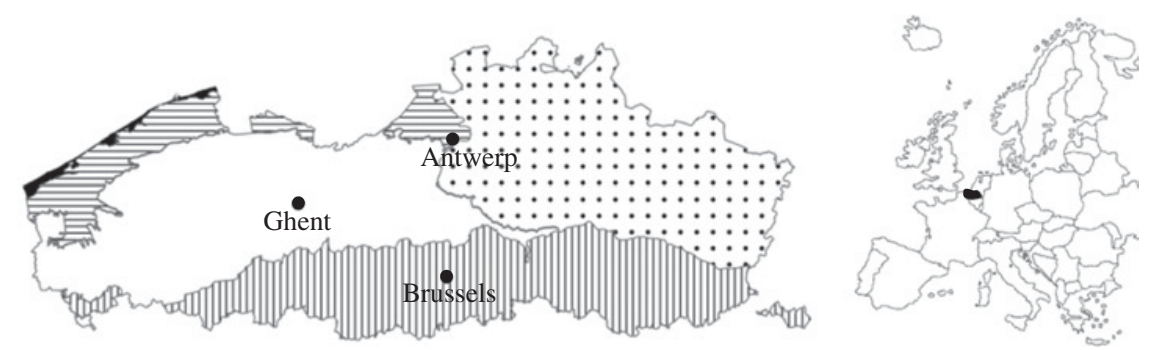

Fig. 1. Map of Flanders with indication of the different ecoregions: dune area (black), polder area (horizontal stripes), sandy region (white), Campine region (dots) and loamy region (vertical stripes); the location of Flanders has been marked on the map of Europe.

has a population of 6.2 million inhabitants and a high population density of 456 citizens $/ \mathrm{km}^{2}$. About $88 \%$ is connected to a sewage system, but only $70.3 \%$ is actually treated (VMM, 2009). Flanders is also heavily industrialized and the agriculture causes a heavy pressure because $53 \%$ of the land is used for (mainly intensive) agriculture (VMM, 2009). In addition, thousands of weirs have been built for flood control, hundreds of kilometres of artificial banks have been installed and the majority of the river channels have been straightened. At the moment, most attention is focused on the watercourses with the poorest water quality. Ameliorating water quality from bad to poor or moderate will, however, not help populations of sensitive organisms such as caddisflies. Priority should be given to the protecting of sites that still have a high water quality and intentional interventions are needed that are directed to the connection of isolated populations by solving the bottlenecks that prevent the necessary expansion of the remaining populations. Ecological models could be useful for the assessment of these bottlenecks in the river basin and could promote an efficient allocation of restoration efforts (Mouton et al., 2008).

Although caddisflies are known as sensitive indicators of the water quality in stagnant as well as running waters, they hardly received attention in Flanders. Knowledge about their distribution could help to set priorities in water management because waters containing rare species or a high species richness deserve priority in nature conservation. Here, a checklist of the caddisflies occurring in Flanders is presented, distribution maps for all species are plotted and habitat suitability is investigated by assessing under which circumstances different caddisfly species can be found.

\section{Materials and methods}

All available Trichoptera from Flanders and Brussels (Fig. 1) were identified to species level using the identification keys by Lechthaler and Stockinger (2005) for larvae and Malicky (2004) for adults. Most collection material was present in the Royal Belgian Institute for Natural Sciences, where the samples of the Flemish Environment Agency are also stored. In the context of water quality monitoring by the Flemish Environment Agency, macroinvertebrates have been sampled at several thousand sampling points since 1989 . Water quality monitoring is focused especially on running waters, whereas stagnant waters are underrepresented. During monitoring, macroinvertebrates are sampled using a standard handnet, as described by Gabriels et al. (2010). A stretch of 10-20 m is sampled for approximately $5 \mathrm{~min}$. Sampling effort is proportionally distributed over all accessible aquatic habitats. This includes the bed substrate (stones, sand or mud), macrophytes (floating, submerging and emerging), immersed roots of overhanging trees and all other natural or artificial substrates, floating or submerged in the water. Each aquatic habitat is explored, in order to collect the highest possible diversity of macroinvertebrates. For this purpose, kick-sampling is performed. In addition to the handnet sampling, animals are manually picked from stones, leaves or branches. At each sampling point, conductivity, $\mathrm{pH}$, oxygen content and water temperature are measured. As the highest point in the study area has an altitude of only $288 \mathrm{~m}$, the whole region can be considered as lowland.

To analyse the distribution and the ecological preferences of caddisflies, literature data as well as all available data from collections and the water quality monitoring data from the Flemish Environment Agency were brought together in one database. In addition, about 50 field trips were carried out during the last 2 years to collect missing data. However, only the monitoring data of the Flemish Environment Agency could be linked to environmental variables. A direct gradient analysis was applied to determine which environmental parameters might be responsible for the differences in species composition, since environmental variables were explicitly incorporated in the analysis. To test whether a linear or unimodal method was needed, a Detrended Correspondence Analysis (DCA) was performed. Since the Length of Gradient (LoG) was greater than four, a unimodal method was needed and therefore, the Canonical Correspondence Analysis (CCA) option from the program package CANOCO (Ter Braak, 1988) was applied. A log-transformation $(\log (x+1))$ was applied prior to the CCA to normalize the data.

\section{Results}

More than 60000 caddisflies were identified during the present study, which represented 8315 records. Of the 126 species that were recorded for Flanders and Brussels 
(Tab. 1), 13 were not previously reported: Athripsodes albifrons, Ceraclea albimacula, Hydropsyche fulvipes, $\mathrm{Hy}$ dropsyche instabilis, Hydropsyche saxonica, Hydropsyche siltalai, Parachiona picicornis, Philopotamus montanus, Potamophylax rotundipes, Rhadicoleptus alpestris, Rhyacophila dorsalis, Silo pallipes and Tinodes unicolor. On the other hand, 16 species have not been observed since 1950: Anabolia brevipennis, Ceraclea annulicornis, Cheumatopsyche lepida, Ernodes articularis, Hydroptila pulchricornis, Limnephilus bipunctatus, Limnephilus centralis, Limnephilus fuscicornis, Limnephilus ignavus, Limnephilus luridus, Limnephilus nigriceps, Limnephilus politus, Limnephilus vittatus, P. montanus, Polycentropus flavomaculatus and Potamophylax luctuosus. The remaining species have all been observed since 1990, but often have a restricted distribution. Distribution maps of all the caddisfly species occurring in Flanders and Brussels before 1990 (॰) and since $1990(\bullet)$, with indication of the ecoregions and a grid of $5 \times 5 \mathrm{~km}$ UTM-squares, are presented in the supporting material (see online material).

Caddisflies were usually found in waters with high oxygen content and were rarely observed in waters with oxygen content below 6 mg. $1^{-1}$ (Fig. 2). Caddisflies also did not tolerate high conductivities and were hardly found at conductivities above $1000 \mu \mathrm{S} . \mathrm{cm}^{-1}$. Most species occurred in waters with a circumneutral $\mathrm{pH}$, but species that were restricted to the loamy region, such as Hydroptila vectis, mainly occurred in waters with a higher $\mathrm{pH}$ (Fig. 2).

In a CCA (Fig. 3), pH explained most of the variation along the first axis, which had an eigenvalue of 0.23 . Conductivity and oxygen content explained most of the variation along the second axis, which had an eigenvalue of 0.09 . Species in the upper half of the plot were mainly species from stagnant waters, which were characterized by a relatively high conductivity and relatively low oxygen content (Fig. 3). The lower left corner of the plot contained species from the running waters in the loamy region, which were characterized by a high $\mathrm{pH}$, a relatively high conductivity and high oxygen content (Fig. 3). The lower right corner contained species from the running waters in the Campine region, which were characterized by a lower $\mathrm{pH}$ and very low conductivities (Fig. 3). Species from running waters occurring in several ecoregions were plotted more towards the centre of the plot.

\section{Discussion}

No endemic species are present in Flanders or Belgium. Most species recorded in Flanders have a West Palaearctic or even a Transpalaearctic distribution. This type of distribution is typical for lowland aquatic invertebrates. Using the categories proposed by the IUCN Species Survival Commission (IUCN Species Survival Commission, 1994) and adapted for Flanders (Maes and Van Swaay, 1997; Maes et al., 2003), the caddisflies were divided into categories according their rarity. Of the previously reported 126 species (Tab. 1, supporting material),
16 species are probably regionally extinct in Flanders since these were all not observed since 1950. However, some stagnant water species of the genera Anabolia, Hydroptila and Limnephilus might have been overlooked, because their habitats have not been sampled intensively. Of the remaining species, 63 are very rare and occur in less than $2 \%$ of the $5 \times 5 \mathrm{~km} \mathrm{UTM}$ squares, 16 species are rare and occur in less than $5 \%$ of the squares and 26 species are fairly rare as they occur in less than $15 \%$ of the squares. Only 5 species are not rare in Flanders: Ecnomus tenellus, Glyphotaelius pellucidus, Hydropsyche angustipennis, Limnephilus lunatus and Mystacides longicornis. A lot of caddisfly species in Flanders can be considered endangered and the populations of some species are especially vulnerable since they are restricted to springs located in isolated forest remnants. Species that are restricted to large streams, such as $C$. annulicornis and C. lepida, still do not stand a chance in Flanders. Among river macroinvertebrates, only stoneflies seem to be worse off, with barely one species present in more than $10 \%$ of the squares (Lock and Goethals, 2008).

In the present study, three assemblages of caddisflies could be recognized: species occurring in stagnant waters, species from running waters in the Campine region and species from running waters in the loamy region. The sandy region and especially the polder and the dune area only contained an impoverished caddisfly fauna, which mainly consisted of ubiquist species. Recently, Gombeer et al. (2011) sampled Trichotpera in 41 Flemish streams with a stream order $\leq 3$ and observed 34 taxa, half of which was only captured at one site. As in the present study, they also found that stagnant waters differed in species composition from running waters. In addition, four clusters of running waters were recognized, which were reported to mainly differ in stream size (Gombeer et al., 2011). However, this separation is probably artificial due to the low number of sites because in the present study, differences between ecoregions were found to be much more important than stream size. Caddisflies are reported as sensitive species (Gabriels et al., 2010), which could be confirmed here as all the species were largely restricted to waters with an oxygen content above $6 \mathrm{mg} . \mathrm{l}^{-1}$ and a conductivity below $1000 \mu \mathrm{S} . \mathrm{cm}^{-1}$. Whereas mayflies (Ephemeroptera), which is another order of sensitive aquatic insects, contain several species in the families Baetidae and Caenidae that are relatively tolerant (Lock and Goethals, 2011), this is not the case for caddisflies in Flanders, despite the much higher species diversity in the latter order.

As the network of the Flemish Environment Agency is very elaborate, it can be assumed that the maps give a good idea of the present distribution of the mayfly species occurring in running waters. However, less information is available about the species living in stagnant waters because these types of waters are not monitored routinely by the Flemish Environment Agency. Some stagnant water species, such as those of the genus Limnephilus, might therefore be more common than indicated by the distribution maps. Despite this limitation, the Flemish caddisfly fauna was found to be very similar to the one observed in 
Table 1. Checklist of the Flemish Trichoptera.

\author{
ORDER TRICHOPTERA \\ Family Glossosomatidae \\ 1. Agapetus fuscipes Curtis 1834 \\ Family Rhyacophilidae \\ 2. Rhyacophila dorsalis (Curtis 1834) \\ 3. Rhyacophila fasciata Hagen 1859 \\ Family Philopotamidae \\ 4. Philopotamus montanus (Donovan 1813) \\ 5. Wormaldia occipitalis (Pictet 1834) \\ Family Hydroptilidae \\ 6. Agraylea multipunctata Curtis 1834 \\ 7. Agraylea sexmaculata Curtis 1834 \\ 8. Hydroptila pulchricornis Pictet 1834 \\ 9. Hydroptila sparsa Curtis 1834 \\ 10. Hydroptila vectis Curtis 1834 \\ 11. Orthotrichia costalis (Curtis 1834) \\ 12. Oxyethira flavicornis Pictet 1834 \\ 13. Tricholeiochiton fagesii (Guinard 1879)
}

\section{Family Polycentropidae}

14. Cyrnus crenaticornis (Kolenati 1859)

15. Cyrnus flavidus McLachlan 1864

16. Cyrnus insolutus McLachlan 1878

17. Cyrnus trimaculatus (Curtis 1834)

18. Holocentropus dubius (Rambur 1842)

19. Holocentropus picicornis (Stephens 1836)

20. Holocentropus stagnalis (Albarda 1874)

21. Neureclipsis bimaculata (Linnaeus 1758)

22. Plectrocnemia conspersa (Curtis 1834)

86. Limnephilus affinis Curtis 1834

23. Polycentropus flavomaculatus (Pictet 1834)

24. Polycentropus irroratus Curtis 1835

Family Ecnomidae

25. Ecnomus tenellus (Rambur 1842)

Family Psychomyiidae

26. Lype phaeopa (Stephens 1836)

27. Lype reducta (Hagen 1868)

28. Psychomyia pusilla (Fabricius 1781)

29. Tinodes assimilis McLachlan 1865

30. Tinodes maculicornis (Pictet 1834)

31. Tinodes unicolor (Pictet 1834)

32. Tinodes waeneri (Linnaeus 1758)

\section{Family Hydropsychidae}

33. Cheumatopsyche lepida (Pictet 1834)

34. Hydropsyche angustipennis (Curtis 1834)

35. Hydropsyche contubernalis McLachlan 1865

36. Hydropsyche fulvipes Curtis 1834

37. Hydropsyche instabilis (Curtis 1834)

38. Hydropsyche pellucidula (Curtis 1834)

39. Hydropsyche saxonica McLachlan 1884

40. Hydropsyche siltalai Doehler 1963

\section{Family Phryganeidae}

41. Agrypnia obsoleta (Hagen 1864)

42. Agrypnia pagetana Curtis 1835

43. Agrypnia varia (Fabricius 1793)

44. Hagenella clathrata (Kolenati 1848)

45. Oligostomis reticulata (Linnaeus 1761)

46. Oligotricha striata (Linnaeus 1758)

47. Phryganea bipunctata Retzius 1783

48. Phryganea grandis Linnaeus 1758

49. Trichostegia minor (Curtis 1834)

Family Lepidostomatidae

50. Molanna angustata Curtis 1834

51. Molannodes tinctus (Zetterstedt 1840)

\section{Family Leptoceridae}

52. Adicella reducta (McLachlan 1865)

53. Athripsodes albifrons (Linnaeus 1758)

54. Athripsodes aterrimus (Stephens 1836)

55. Athripsodes cinereus (Curtis 1834)

56. Ceraclea albimacula (Rambur 1842)

57. Ceraclea annulicornis (Stephens 1836)

58. Ceraclea dissimilis (Stephens 1836)
59. Ceraclea fulva (Rambur 1842)

60. Ceraclea senilis (Burmeister 1839)

61. Leptocerus tineiformis Curtis 1834

62. Mystacides azurea (Linnaeus 1761)

63. Mystacides longicornis (Linnaeus 1758)

64. Mystacides nigra (Linnaeus 1758)

65. Oecetis furva (Rambur 1842)

66. Oecetis lacustris (Pictet 1834)

67. Oecetis notata (Rambur 1842)

68. Oecetis ochracea (Curtis 1825)

69. Oecetis testacea (Curtis 1834)

70. Triaenodes bicolor (Curtis 1834)

\section{Family Goeridae}

71. Goera pilosa (Fabricius 1775)

72. Lithax obscurus (Hagen 1859)

73. Silo pallipes (Fabricius 1781)

Family Limnephilidae

74. Anabolia brevipennis (Curtis 1834)

75. Anabolia nervosa (Curtis 1834)

76. Chaetopteryx major McLachlan 1876

77. Chaetopteryx villosa (Fabricius 1798)

78. Drusus annulatus (Stephens 1837)

79. Enoicyla pusilla (Burmeister 1839)

80. Glyphotaelius pellucidus (Retzius 1783)

81. Grammotaulius nigropunctatus (Retzius 1783)

82. Grammotaulius nitidus (Muller 1764)

83. Halesus digitatus (von Paula Schrank 1781)

84. Halesus radiatus (Curtis 1834)

85. Ironoquia dubia (Stephens 1837)

86. Limnephilus affinis Curtis 1834

87. Limnephilus auricula Curtis 1834

88. Limnephilus binotatus Curtis 1834

89. Limnephilus bipunctatus Curtis 1834

90. Limnephilus centralis Curtis 1834

91. Limnephilus decipiens (Kolenati 1848)

92. Limnephilus elegans Curtis 1834

93. Limnephilus extricatus McLachlan 1865

94. Limnephilus flavicornis (Fabricius 1787)

95. Limnephilus fuscicornis Rambur 1842

96. Limnephilus griseus (Linnaeus 1758)

97. Limnephilus hirsutus (Pictet 1834)

98. Limnephilus ignavus McLachlan 1865

99. Limnephilus incisus Curtis 1834

100. Limnephilus lunatus Curtis 1834

101. Limnephilus luridus Curtis 1834

102. Limnephilus marmoratus Curtis 1834

103. Limnephilus nigriceps (Zetterstedt 1840)

104. Limnephilus politus McLachlan 1865

105. Limnephilus rhombicus (Linnaeus 1758)

106. Limnephilus sparsus Curtis 1834

107. Limnephilus stigma Curtis 1834

108. Limnephilus vittatus (Fabricius 1798)

109. Micropterna lateralis (Stephens 1837)

110. Micropterna sequax McLachlan 1875

111. Parachiona picicornis (Pictet 1834)

112. Potamophylax cingulatus (Stephens 1837)

113. Potamophylax luctuosus (Piller \& Mitterpacher 1783)

114. Potamophylax nigricornis (Pictet 1834)

115. Potamophylax rotundipennis (Brauer 1857)

116. Rhadicoleptis alpestris (Kolenati 1848)

117. Stenophylax permistus McLachlan 1895

Family Lepidostomatidae

118. Crunoecia irrorata (Curtis 1834)

119. Lasiocephala basalis (Kolenati 1848)

Family Sericostomatidae

120. Notidobia ciliaris (Linnaeus 1761)

121. Sericostoma personatum (Kirby \& Spence 1826)

122. Sericostoma schneideri Kolenati 1848

Family Beraeidae

123. Beraea maurus (Curtis 1834)

124. Beraea pullata (Curtis 1834)

125. Beraeodes minutus (Linnaeus 1761)

126. Ernodes articularis (Pictet 1834) 

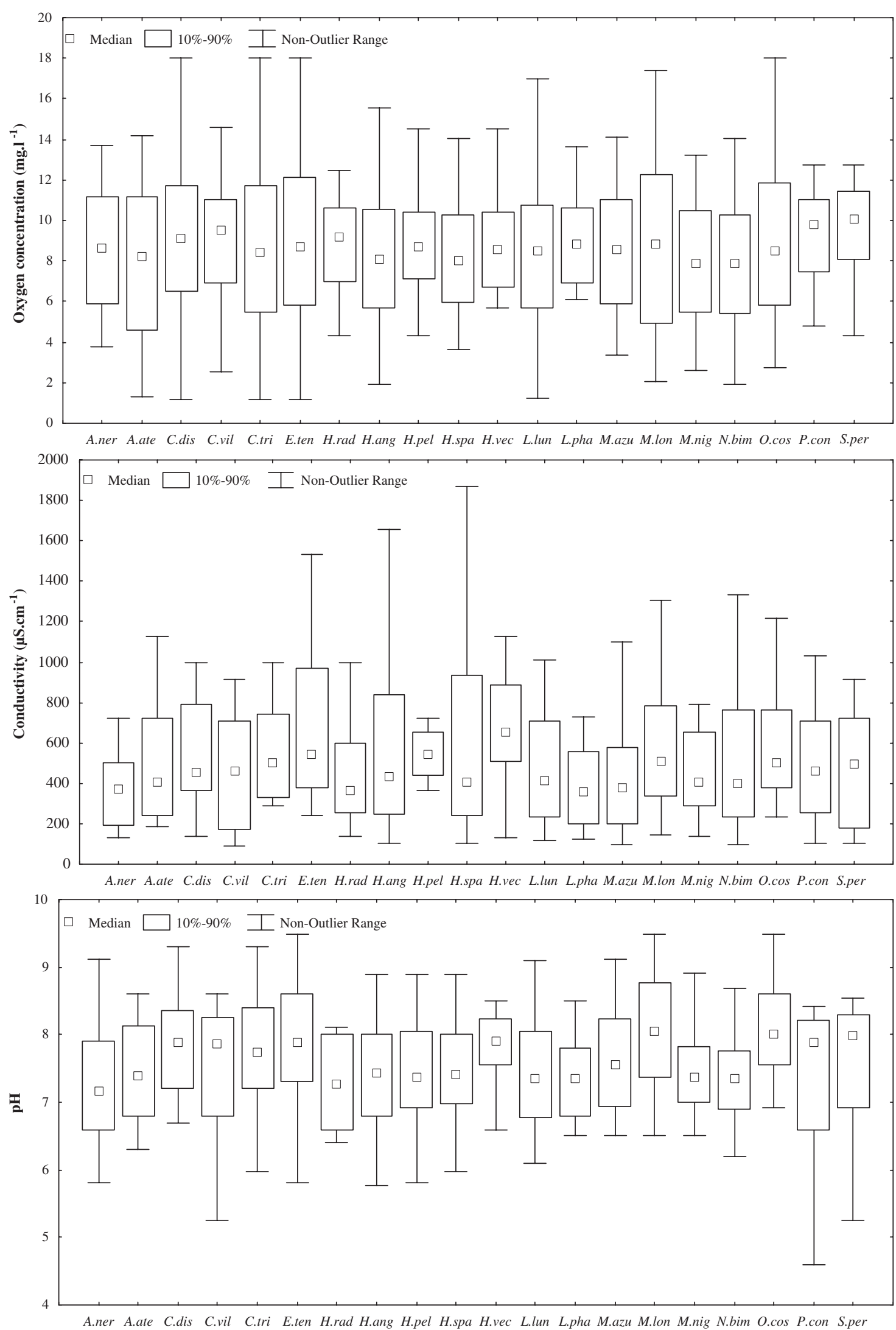

Fig. 2. Box and Whisker plots of oxygen concentration, conductivity and $\mathrm{pH}$ for the 20 most widespread caddisflies occurring in the studied watercourses. Species are indicated by the first letter of the genus name followed by the first three letters of the species name. 


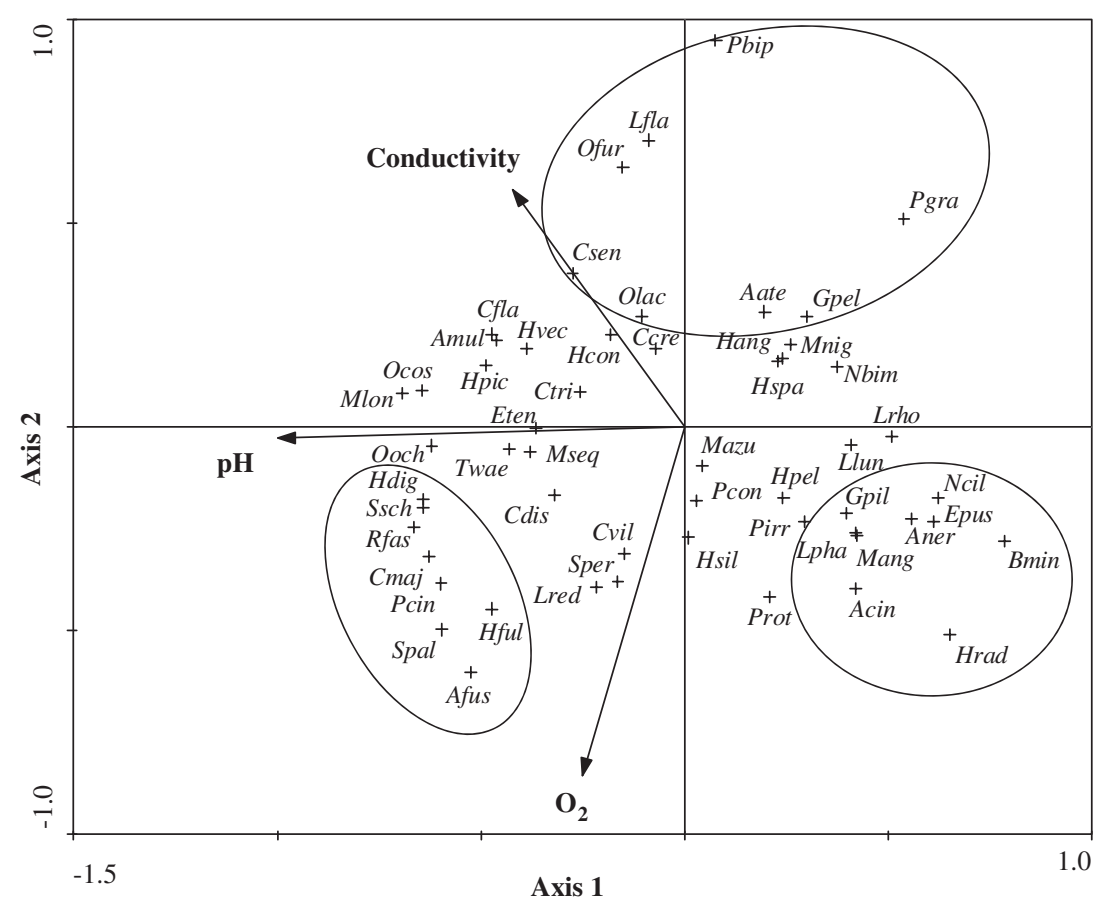

Fig. 3. CCA biplot of the species scores and the environmental variables pH, conductivity and oxygen concentration. Species are indicated by the first letter of the genus name followed by the first three letters of the species name. Species characteristic for the loamy region (lower left), the Campine region (lower right) and stagnant or slow flowing waters (top) are encircled.

the Netherlands (Higler, 2008). However, the caddisfly richness in the south of Belgium (Stroot, 1984) and in the Grand Duchy of Luxembourg (Schrankel et al., 2008) is much higher, which can be related not only to a lower human impact but also to a more diverse geomorphology.

The effect of climate change is expected to be of much lesser importance on stream macroinvertebrates than the effect of future land-use change (Verdonschot, 2009). Based on species traits, the proportion of caddisfly species threatened by climate change is expected to be less than $3 \%$ in lowland ecoregions such as Flanders (Hering et al., 2009). This was explained by the fact that species that colonized northern Europe after the Pleistocene have generally a large geographical range and are mainly generalists with a high dispersal capacity, which are therefore expected to be able to cope with climate change impacts. In Flanders, Hagenella clathrata, Ironoquia dubia, Limnephilus elegans, L. politus and Molannodes tinctus can be expected to disappear in a global warming scenario, because they reach their southernmost distribution edge in or close to Flanders.

\section{Conclusion}

Of the 126 caddisfly species that have been recorded in Flanders, 16 became extinct, while many of the remaining species are rare. A majority of the waters in Flanders still do not contain any caddisflies since these sensitive aquatic insects only live in waters with a high oxygen content and conductivity that is not too high. It can only be hoped that the WFD will encourage Flanders to undertake the necessary steps to achieve an ecological water quality that is sufficient to support sustainable populations of sensitive aquatic invertebrates such as caddisflies.

Acknowledgements. We thank the Royal Belgian Institute of Natural Sciences, the Flemish Environment Agency, the Research Institute for Nature and Forest and the Catholic University of Leuven for providing the opportunity to study their collections. For the help during the study of the collections, we thank Rose Sablon, Thierry Backeljou, Jérôme Constant, Patrick Grootaert and Baudewijn Goddeeris (Royal Belgian Institute of Natural Sciences), Erik Ghyselbrecht, Joost Mertens, Thierry Warmoes, Christophe Maes, Saskia Scheers, Frank Lavens, Dirk Roos and Wim Gabriels (Flemish Environment Agency), Jo Packet (Research Institute for Nature and Forest) and Frank Van de Meutter (Catholic University of Leuven). Finally, we thank Tim Adriaens from the Research Institute for Nature and Forest for plotting the distribution maps. Koen Lock is currently supported by a post-doctoral fellowship from the Fund for Scientific Research (FWO-Vlaanderen, Belgium).

\section{References}

De Pauw N. and Vanhooren G., 1983. Method for biological quality assessment of watercourses in Belgium. Hydrobiologia, 100, 153-168.

European Council, 2000. Directive 2000/60/EC of the European Parliament and of the Council of 23 October 2000 establishing a framework for Community action in the field of water policy. Official Journal of the European Communities L327, 72 p. 
Gabriels W., Lock K., De Pauw N. and Goethals P.L.M., 2010. Multimetric Macroinvertebrate Index Flanders (MMIF) for biological assessment of rivers and lakes in Flanders (Belgium). Limnologica, 40, 199-207.

Gombeer S., Knapen D. and Bervoets L., 2011. The influence of different spatial-scale variables on caddisfly assemblages in Flemish lowland streams. Ecol. Entomol., 36, 355-368.

Hering D., Schmidt-Kloiber A., Murphy J., Lücke S., ZamoraMuñoz C., López-Rodríguez M.J., Huber T. and Graf W., 2009. Potential impact of climate change on aquatic insects: a sensitivity analysis for European caddisflies (Trichoptera) based on distribution patterns and ecological preferences. Aquat Sci., 71, 3-14.

Higler, L.W.G., 2008. Verspreidingsatlas Nederlandse kokerjuffers (Trichoptera), European Invertebrate Survey - the Netherlands, Leiden.

IUCN Species Survival Commission, 1994. IUCN Red List Categories, IUCN, Gland, $21 \mathrm{p}$.

Lechthaler W. and Stockinger W., 2005. Trichoptera - Key to Larvae from Central Europe, Eutaxa, Vienna.

Lock K. and Goethals P.L.M., 2008. Distribution and ecology of the stoneflies (Plecoptera) of Flanders (Belgium). Ann. Limnol. - Int. J. Lim., 44, 203-213.

Lock, K. and Goethals, P.L.M. 2011. Distribution and ecology of the mayflies (Ephemeroptera) of Flanders (Belgium). Ann. Limnol. - Int. J. Lim., 47, 159-165.

Maes D. and Van Swaay C.A.M., 1997. A new methodology for compiling national Red Lists applied to butterflies (Lepidoptera, Rhopalocera) in Flanders (N-Belgium) and the Netherlands. J. Insect Conserv., 1, 113-124.

Maes D., De Bruyn L. and Kuijken E., 2003. Red list criteria in Flanders. In: de Iongh H.H., Bánki O.S., Bergmans W. and van der Werff M.J. (eds.), Harmonization of Red Lists in Europe, Proceedings International Seminar, 27-28 November 2002, The Netherlands Foundation for International Nature Protection, Mededelingen No. 38, Leiden, 217-223.

Malicky H. 2004. Atlas of European Trichoptera (2nd edn), Series Entomologica 24, Dr W. Junk Publishers, The Hague.
Messiaen M., Lock K., Gabriels W., Vercauteren T., Wouters K., Boets P. and Goethals P.L.M., 2010. Alien macrocrustaceans in freshwater ecosystems in the eastern part of Flanders (Belgium). Belg. J. Zool., 140, 30-39.

Mouton A.M., Van der Most H., Jeuken A., Goethals P.L.M. and De Pauw N., 2008. Evaluation of river basin restoration options by the application of the water framework directive explorer in the Zwalm River basin (Flanders, Belgium). River Res. Appl., 23, 1-16.

Sala O.E., Chapin F.S., Armesto J.J., Berlow R., Bloomfield J., Dirzo R., Huber-Sanwald E., Huenneke L.F., Jackson R.B., Kinzig A., Leemans R., Lodge D., Mooney H.A., Oesterheld M., Poff N.L., Sykes M.T., Walker B.H. and Wall D.H., 2000. Global biodiversity scenarios for the year 2100 . Science, 287, 1770-1774.

Schrankel I., Neu P., Dohet A. and Schoos F., 2008. Checklist of the Trichoptera of the Grand Duchy of Luxembourg - first revision. Ferrantia, 55, 89-92.

Smith V.H., 2003. Eutrophication of freshwater and coastal marine ecosystems - a global problem. Environ. Sci. Pollut. Res., 10, 126-139.

Stroot P., 1984. Les trichoptères de Belgique et des regions limitrophes (225 cartes), Institut Royal des Sciences Naturelles de Belgique, Bruxelles.

Ter Braak C.J.F., 1988. CANOCO - a FORTRAN program for canonical community ordination by (partial) (canonical) correspondence analysis, principal components analysis and redundancy analysis (version 2.1), Agricultural Mat, Group, Ministry of Agriculture and Fisheries (Netherlands), Wageningen, $95 \mathrm{p}$.

Verdonschot P.F.M., 2009. The significance of climate change in streams utilised by humans. Fund. Appl. Limnol., 174, 101-116.

VMM, 2009. MIR-T 2008 Indicator Report [in Dutch]. In: Van Steertegem M. (red.), Environmental Report Flanders, Flemish Environment Agency, Aalst, 164 p.

VMM, 2010. Annual Report Water 2009 [in Dutch], Flemish Environment Agency, Available online at: http:// www.vmm.be/pub/jaarrapport-water-2009. 